\title{
Colonic Electrolyte Transport in Health and in Congenital Chloride Diarrhea
}

\author{
Chruster Holmberg, JaAkxo Perheentupa, and Karu Launiala \\ From the Children's Hospital, University of Helsinki, \\ Helsinki, Finland, SF 00290
}

A в S T R A C T Congenital chloride diarrhea (CCD) is a rare autosomal recessive disorder, characterized by watery stools with $\mathrm{Cl}^{-}$concentration around $150 \mathrm{meq} /$ liter. We have perfused the colon of three patients and their three healthy siblings with different salt solutions containing ${ }^{36} \mathrm{Cl}^{-}$to determine the nature of the colonic defect in CCD.

In the controls, net absorption of $\mathrm{Na}^{+}$and $\mathrm{Cl}^{-}$occurred against steep concentration gradients. The influx (lumen-to-plasma flux) of $\mathrm{Cl}^{-}$was twice the efflux. Omission of $\mathrm{HCO}_{3}{ }^{-}$from the perfusate caused a clear decrease in $\mathrm{Cl}^{-}$efflux, which suggests a coupling of $\mathrm{Cl}^{-}$ efflux to $\mathrm{HCO}_{3}^{-}$influx.

In $\mathrm{CCD}$, net $\mathrm{Na}^{+}$absorption occurred normally when $\mathrm{HCO}_{3}^{-}$was present in the lumen. However, $\mathrm{Na}^{+}$absorption was always impaired when the luminal contents were acid, a situation that prevails in CCD. Net $\mathrm{K}^{+}$secretion was clearly increased. Both influx and efflux of $\mathrm{Cl}^{-}$were practically absent. Only slight net secretion occurred along a steep gradient. Net appearance of $\mathrm{HCO}_{3}^{-}$ was not observed, in contrast to controls.

These findings and earlier studies of ileal function in $\mathrm{CCD}$ are best explained by a defect in the $\mathrm{Cl}^{-} / \mathrm{HCO}^{-}$ exchange mechanism, which operates in both directions in the normal ileum and colon.

\section{INTRODUCTION}

Since Gamble, Fahey, Appleton, and MacLachlan and Darrow first described congenital chloride diarrhea $(C C D)^{1}$ in 1945 , a total of 20 cases has accumulated in

\footnotetext{
A preliminary report was presented at the 6th Annual Meeting of the European Society for Pediatric Gastroenterology, Helsinki, Finland, August 1973, and at the Annual Meeting of the European Society for Pediatric Research, Seville, Spain, October 1973.

Received for publication 5 July 1974 and in revised form 31 March 1975.

${ }^{1}$ Terms and abbreviations used in this paper: Efflux, plasma-to-lumen flux; influx, lumen-to-plasma flux; CCD, congenital chloride diarrhea; ECF, extracellular fluid. PEG, polyethylene glycol.
}

the literature from outside Finland (1-10). In Finland we have observed 21 cases. $^{2}$ This autosomal recessive (4) disease is manifested by hydramnios, presumably due to intrauterine diarrhea and, from the first day of life, by large watery stools with a high $\mathrm{Cl}^{-}$concentration (above $60 \mathrm{meq} /$ liter in the newborn, and above $100 \mathrm{meq}$ / liter later). These features constitute the diagnostic criteria of CCD. Solid stools and lower $\mathrm{Cl}^{-}$concentrations have been observed only in chronic dehydration. ${ }^{2}$ The diarrhea results in excessive neonatal loss of weight with dehydration and jaundice. Hyponatremia and hypochloridemia develop rapidly and, later, hypokalemia and metabolic alkalosis. Unless they receive proper treatment, most patients die in the first few weeks of life (4) from hypokalemia and dehydration, but some survive with chronic dehydration and variable general retardation. The appropriate treatment, lifelong oral replacement of the fecal loss of electrolytes and water, enables the children to develop normally. ${ }^{2}$

The nature of the basic intestinal defect is unclear. Launiala, Perheentupa, Pasternack, and Hallman showed that the defect must be in the distal ileum and the colon (11). Recently, three reports of ileal perfusion studies in single patients have appeared. Turnberg (12) found increased secretion of $\mathrm{Cl}^{-}$and postulated that ileal $\mathrm{Cl}^{-} /$ $\mathrm{HCO}^{-}$exchange (13) was working in reverse, i.e. secreting $\mathrm{Cl}^{-}$and absorbing $\mathrm{HCO}_{3}^{-}$. Bieberdorf, Gorden, and Fordtran (14) observed absence of active transfer of $\mathrm{Cl}^{-}$; passive movement occurred according to the concentration gradient. Pearson et al. (7) reported that no $\mathrm{Na}^{+}$or $\mathrm{Cl}^{-}$movement took place in the ileum. They also perfused the sigmoid, the only part of the colon remaining after operations done on their patient, and the same defect appeared to be present. Lauras et al. (10) introduced ${ }^{82} \mathrm{Br}^{-}$into the rectum of two patients and found almost none of it in the serum, in contrast to controls. They concluded that absorption of $\mathrm{Cl}^{-}$was decreased.

${ }^{2}$ Holmberg, C., J. Perheentupa, K. Launiala, and N. Hallman. An extensive clinical report is in preparation. 
To elucidate the nature of the colonic defect in CCD and to add to our knowledge of normal transport, we have performed colonic perfusions with ${ }^{96} \mathrm{Cl}^{-}$in three CCD patients and their three healthy siblings. In the controls $\mathrm{Cl}^{-}$efflux was found to be dependent on luminal $\mathrm{HCO}_{3}{ }^{-}$concentration, suggesting a coupling between the efflux of $\mathrm{Cl}^{-}$and influx of $\mathrm{HCO}_{3}^{-}$. In $\mathrm{CCD}$ both influx and efflux of $\mathrm{Cl}^{-}$were greatly reduced. Previous findings for the ileum (14) and the present ones for the colon in $\mathrm{CCD}$ are best explained by absence of active $\mathrm{Cl}^{-} / \mathrm{HCO}_{3}^{-}$exchange in the intestine in this disease.

\section{METHODS}

Patients. A. S. was 10.0 yr old. She was first seen by us at the age of 8 days; the diagnosis of CCD was made at $9 \mathrm{mo}$, and substitution therapy was instituted. During the 1st yr of life her fluid balance was unstable, with periods of alkalosis and once of anuria and hyperphosphatemia. In the last few years she has been doing well and is attending school normally, receiving $5 \mathrm{meq} \mathrm{Cl}^{-} / \mathrm{kg} \cdot$ day as a $\mathrm{NaCl}-$ $\mathrm{KCl}$ solution $(\mathrm{Na} / \mathrm{K}=5 / 1)$. This was continued during the study. Her height was $127.5 \mathrm{~cm}$, weight $26 \mathrm{~kg}$, serum $\mathrm{Na}^{+}$ $140, \mathrm{~K}^{+} 3.7, \mathrm{HCO}_{3}^{-} 24$, and $\mathrm{Cl}^{-} 96 \mathrm{meq} /$ liter. Her stool volume was $1.1-1.5$ liter/day, and the electrolyte concentrations were $\mathrm{Na}^{+} 58-65, \mathrm{~K}^{+} 33-44$, and $\mathrm{Cl}^{-} 100-148 \mathrm{meq} / \mathrm{liter}$.

R. Ko. was $9.5 \mathrm{yr}$ old. She was first admitted to our hospital at the age of 4 days because of abdominal distention, and was found to have hypoelectrolytemia. She did well only when on electrolyte substitution therapy. The diagnosis of CCD was finally made at the age of $8 \mathrm{mo}$. She had since received a continuous $\mathrm{KCl}$ supplement and developed normally. Her present dose of $\mathrm{KCl}, 2 \mathrm{meq} / \mathrm{kg} \cdot$ day, was continued during the period of this study. Her height was 144 $\mathrm{cm}$ and weight $33 \mathrm{~kg}$, serum $\mathrm{Na}^{+}$concentration $142, \mathrm{~K}^{+} 4.2$, $\mathrm{HCO}_{3}^{-} 25$, and $\mathrm{Cl}^{-} 102 \mathrm{meq} /$ liter. Her stool volume was $0.7-1.1$ liter/day and the electrolyte concentrations were $\mathrm{Na}^{+}$ 37-71, $\mathrm{K}^{+}$51-92, and $\mathrm{Cl}^{-} 129-156 \mathrm{meq} / \mathrm{liter}$.

J-P. K. was a 6.5 -yr-old boy, whose CCD was recognized at birth and substitution therapy started immediately. He had been doing perfectly well, receiving the same solution as A. S., at $3 \mathrm{meq} \mathrm{Cl}^{-} / \mathrm{kg} \cdot$ day. His height was $114 \mathrm{~cm}$ and weight $25 \mathrm{~kg}$, serum $\mathrm{Na}^{+} 143, \mathrm{~K}^{+} 4.0, \mathrm{HCO}_{3}^{-} 24$, and $\mathrm{Cl}^{-}$ $101 \mathrm{meq} / \mathrm{liter}$. His stool volume was $1.0-1.2 \mathrm{liter} / \mathrm{day}$, and the electrolyte concentrations were $\mathrm{Na}^{+} 50-81, \mathrm{~K}^{+}$14-38, and $\mathrm{Cl}^{-}$75-144 meq/liter.

Controls. Three healthy siblings of the patients, aged 6.8, 7.8 , and $8.4 \mathrm{yr}$, were studied in the same way.

Perfusions. The procedure was explained in detail to the parents and the children before hospitalization, and all the children were in perfect electrolyte balance and cheerful. They were on a semisolid diet during the period of the study. The colons were perfused with a series of electrolyte solutions (called perfusates in the text). A two-lumen X-raypositive rubber tube was inserted into the cecum via the nose. The perfusion site aimed at was just beyond the ileocaecal valve (Fig. 1). Its actual location was checked by fluoroscopy before and after each perfusion. The location varied between the cecum and the mid-part of the ascending colon.

Perfusions were started at 9 a.m., after a light breakfast, and emptying of the rectum in the controls with Microlax (Pharmacia Fine Chemicals, Uppsala, Sweden), a 5-ml enema that contains $90 \mathrm{mg}$ of Na-citrate and $9 \mathrm{mg}$ of $\mathrm{Na}$ -

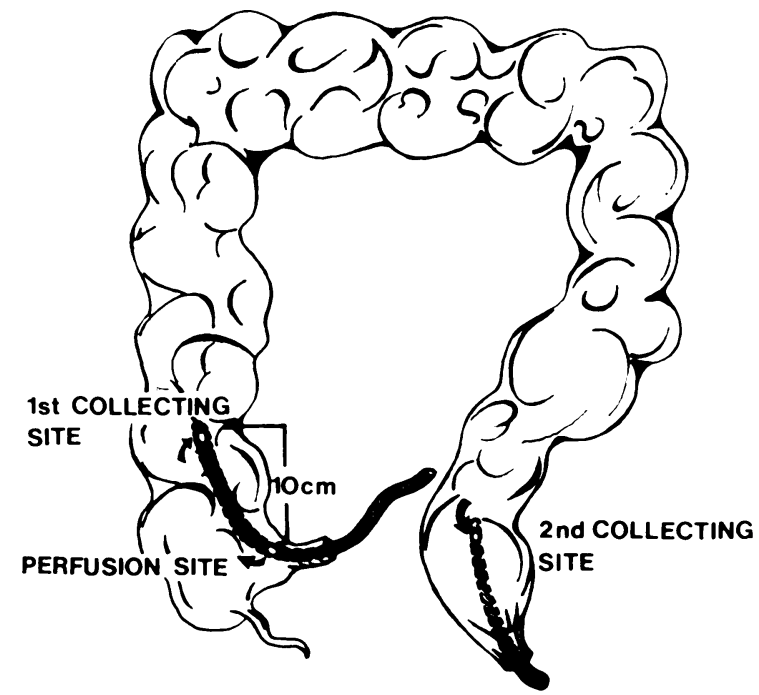

FIGURE 1 The perfusion system.

laurylsulfoacetate. Perfusions were done every 2nd day. Two solutions were used on the same day; the child had a $1-h$ rest and a light meal between the perfusions. The sequence of the perfusates was randomized. The perfusate was pumped at $7.5 \mathrm{ml} / \mathrm{min}$. Collection was started after a steady flow from the rectum had been established. This rinsing period lasted about $30 \mathrm{~min}$. The fluid entering the test segment proper was sampled at the first collecting site, $10 \mathrm{~cm}$ beyond the perfusion site, by continuous siphoning or gentle suction (approximately $0.3 \mathrm{ml} / \mathrm{min}$ ) and the fluid leaving the segment was collected by drainage through a rectal tube (second collecting site). Thus the aim was to use the entire colon, save a $10-\mathrm{cm}$ mixing segment, as a test segment. With every solution, collections were made in periods of $20 \mathrm{~min}$ for 2-3 h. The electrolyte composition of the perfusates used is given in Table I; mannitol was added when necessary to achieve isosmolality. All perfusates contained polyethylene glycol (PEG) $5 \mathrm{~g} /$ liter. The $\mathrm{Cl}^{-}$perfusates contained $0.5 \mu \mathrm{Ci} /$ liter ${ }^{38} \mathrm{Cl}^{-}$(The Radiochemical Centre, Amersham, England). The $\mathrm{HCO}_{3}^{-}$-containing perfusates were bubbled with $\mathrm{O}_{2}-\mathrm{CO}_{2}(95: 5)$ for 30 min before and during the perfusions. All perfusates were kept in a water bath at $37^{\circ} \mathrm{C}$.

Analytical methods. Electrolyte concentrations were measured by standard methods, PEG by a modification of the

TABLE I

Ion Composition of the Perfusates

\begin{tabular}{crrrrl}
\hline $\begin{array}{c}\text { Per- } \\
\text { fusate }\end{array}$ & $\mathrm{Na}^{+}$ & \multicolumn{1}{c}{$\mathrm{K}^{+}$} & $\mathrm{Cl}^{-}$ & $\mathrm{HCO}_{3}-$ & Other \\
\hline \multicolumn{5}{c}{ meq/liter } \\
1 & 140 & 10 & 125 & 25 & \\
2 & 140 & 10 & 60 & 25 & Sulfate \\
3 & 140 & 10 & 0 & 25 & Sulfate \\
4 & 140 & 10 & 125 & 0 & Sulfate \\
5 & 0 & 0 & 120 & 0 & Choline \\
6 & 0 & 0 & 0 & 0 & 0.3 M mannitol \\
\hline
\end{tabular}




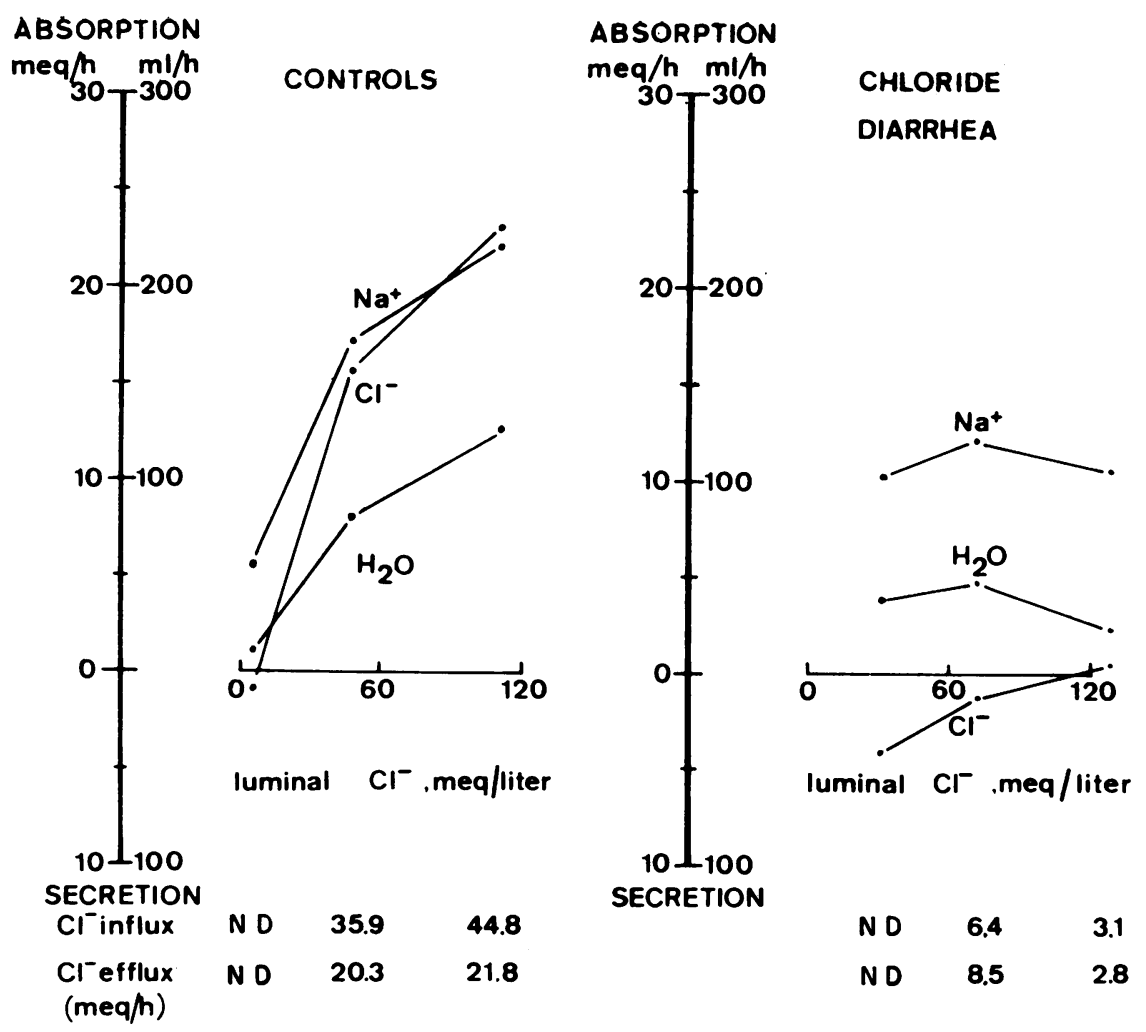

Figure 2 Mean net ion and water movement in sequential perfusions of the colon with solutions of different $\mathrm{Cl}^{-}$concentrations, in three controls and three patients. The mean $\mathrm{Cl}^{-}$concentration of the fluid in the test segments is given on the horizontal scale. The mean concentrations of $\mathrm{Na}^{+}, \mathrm{K}^{+}$, and $\mathrm{HCO}_{3}{ }^{-}$were 130,11 , and $22 \mathrm{meq} / \mathrm{liter}$ in the controls, and 129,14 , and 12 meq/liter in the patients, respectively. The mean unidirectional $\mathrm{Cl}^{-}$fluxes are given at the bottom. They were not determined (ND) for the $\mathrm{Cl}^{-}$-free perfusates.

method of Hyden (15) and total $\mathrm{HCO}_{3}^{-}$with a Natelson microgasometer (Model 600, Scientific Industries, Inc., Mineola, N. Y.). $\mathrm{pH}$ was measured with a $\mathrm{pH}$ meter $26^{3}$ and $\mathrm{PCO}_{2}$ with a $\mathrm{PCO}_{2}$ electrode Type $\mathrm{E} 5036^{3}$ coupled to an acid-base analyzer $\mathrm{PHM} 71^{8} \mathrm{pH}, \mathrm{PCO}_{2}$, and total $\mathrm{HCO}_{3}^{-}$ were measured immediately from samples taken with a syringe without air contact at the end of each 20 -min collecting period.

Calculations. Calculations were done from a set of consecutive 20-min periods in which electrolyte and PEG concentrations were steady at both collection sites. This was obtained after four to five periods in the controls and after five to six periods in the CCD patients. Ion net absorption and secretion were calculated from the perfusion rate and the changes in the concentrations of PEG and electrolytes in the test segment (16). Unidirectional $\mathrm{Cl}^{-}$fluxes were calculated according to Curran and Solomon (17). In the control child T. Ko. cecal collections failed and the composition of the perfusate was used in the calculations instead of the fluid entering the test segment. This does not entail a substantial error, because admixture of fluid from the ileum was small $(0.9 \mathrm{ml} / \mathrm{min})$ in the controls, in contrast to the CCD patients. Mean concentrations of electrolytes in

${ }^{3}$ Radiometer Co., Copenhagen, Denmark. the colon were calculated arithmetically from the concentrations in the fluid entering and leaving the test segment.

\section{RESULTS}

The data of the individual subjects are given in Table II and some means for the groups in Figs. 2 and 3.

\section{Ileal effluent}

From the difference in composition between the perfusate and the fluid entering the test segment, the electrolyte concentrations and flow rate can be calculated for the fluid being added to the perfusate in the mixing segment. This fluid closely resembles the ileal effluent, because the mixing segment was only $10 \mathrm{~cm}$ long, and its secretory and absorptive contributions thus were minimal. In eight perfusions of the controls, the mean flow rate was 0.9 (range $0.2-1.9$ ) $\mathrm{ml} / \mathrm{min}$ and the mean concentrations of $\mathrm{Na}^{+} 108.3(94.1-125.7), \mathrm{K}^{+} 8.8$ 19.7), $\mathrm{Cl}^{-} 67.9$ (60.1-104.0), and $\mathrm{HCO}_{3}^{-} 25.3$ 97.0) meq/liter. These figures agree with previous observations $(18,19)$. In 12 perfusions of the CCD pa- 


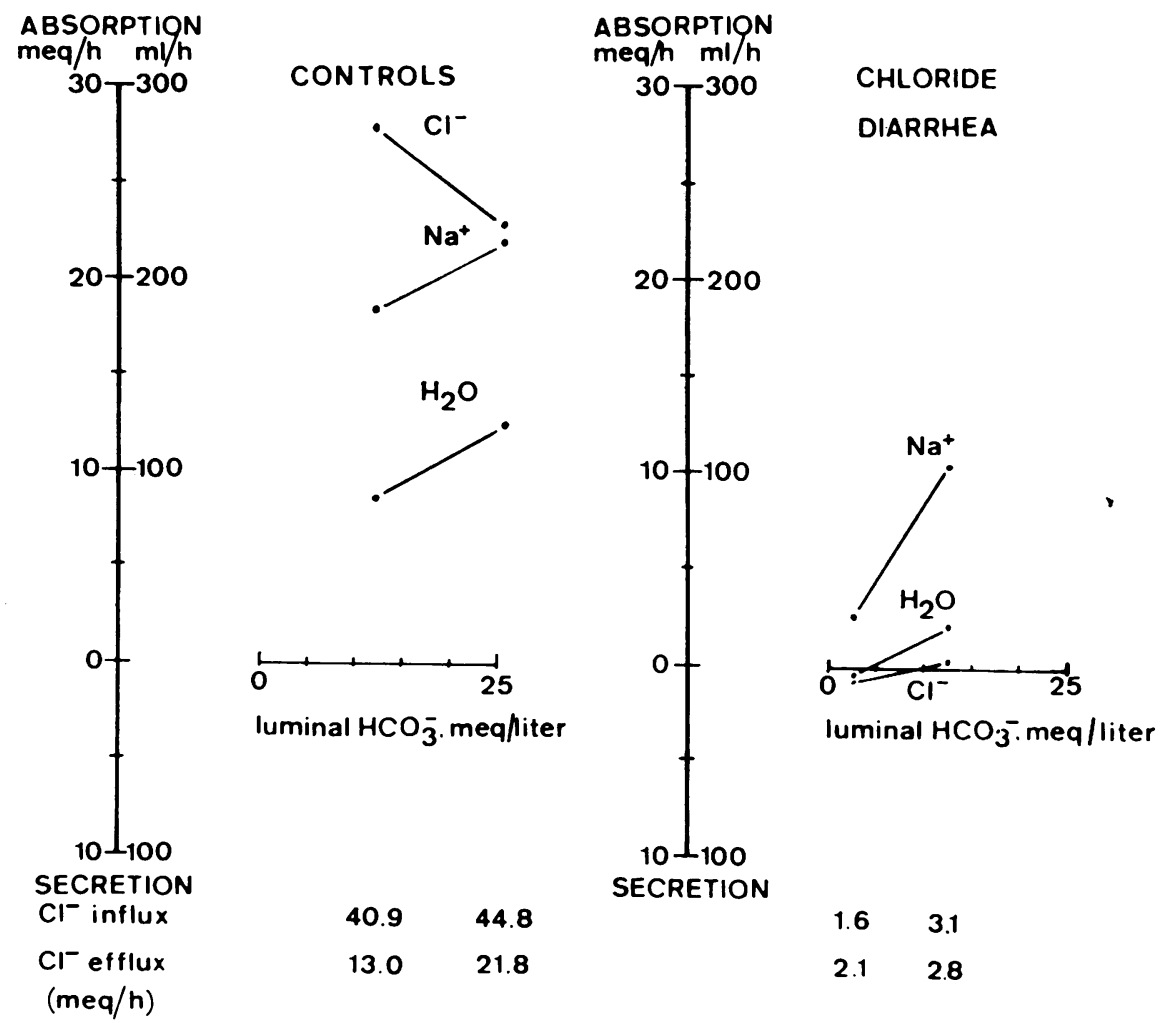

FIGURE 3 Mean net ion and water movement in perfusions of the colon with solutions of different $\mathrm{HCO}_{3}^{-}$concentrations in three controls and three patients. The mean $\mathrm{HCO}_{3}^{-}$concentration of the fluid in the test segment is given on the horizontal scale. The mean concentrations of $\mathrm{Na}^{+}, \mathrm{K}^{+}$, and $\mathrm{Cl}^{-}$were 130,11 , and $103 \mathrm{meq} /$ liter in the controls and 130,11 , and $127 \mathrm{meq} /$ liter in the patients, respectively. The mean unidirectional $\mathrm{Cl}^{-}$fluxes are given at the bottom.

tients, the mean rate was $1.8(1.2-2.6) \mathrm{ml} / \mathrm{min}$ and the concentrations $\mathrm{Na}^{+} 100.0(95.8-134.1), \mathrm{K}^{+} 7.3(1.8-$ 19.8), $\mathrm{Cl}^{-} 118.0$ (85.0-145.0), and $\mathrm{HCO}_{3}^{-} 3.4$ (0.8-15.6) meq/liter. The marked difference in the concentrations of $\mathrm{Cl}^{-}$and $\mathrm{HCO}_{3}^{-}$between the controls and patients is compatible with the view that a defect in the ileal $\mathrm{Cl}^{-} /$ $\mathrm{HCO}_{3}{ }^{-}$exchange in $\mathrm{CCD}(7,12,14)$ is the cause of the increased effluent volume.

\section{Transport of $\mathrm{Cl}^{-}$and $\mathrm{HCO}_{3}^{-}$}

Controls. On perfusion with the extracellular fluid (ECF)-like perfusate 1 , the mean net $\mathrm{Cl}^{-}$absorption was $23.0 \mathrm{meq} / \mathrm{h}$. This was the net result of an efflux and an influx, the influx being twice as great as the efflux. When the luminal $\mathrm{Cl}^{-}$concentration was reduced, the concentrations of $\mathrm{Na}^{+}, \mathrm{K}^{+}$, and $\mathrm{HCO}_{3}^{-}$remaining constant, net $\mathrm{Cl}^{-}$absorption decreased, because of a decrease in influx (Fig. 2). However, net absorption still continued at $\mathrm{Cl}^{-}$ concentrations as low as $10 \mathrm{meq} / \mathrm{liter}$, obtained with the mannitol perfusate (Table II).

When $\mathrm{HCO}_{3}{ }^{-}$was omitted from the ECF-like perfusate, there was a clear decrease in $\mathrm{Cl}^{-}$efflux (Fig. 3).
When $\mathrm{Na}^{+}$and $\mathrm{K}^{+}$were further omitted (choline- $\mathrm{Cl}^{-}$ perfusate) the efflux was unchanged, but there was a marked reduction in influx, the influx and efflux being now of the same magnitude (compare perfusates 5 and 6, Table II).

In perfusions with mean $\mathrm{Cl}^{-}$concentrations of 110 and $47 \mathrm{meq} /$ liter in the segment, there was only a slight net change $(-0.1$ and $-1.5 \mathrm{meq} / \mathrm{h}$, respectively) in the $\mathrm{HCO}_{3}{ }^{-}$content (perfusates 1 and 2, Table II). When all $\mathrm{Cl}^{-}$was omitted (perfusate 3 ), there was a clear net disappearance of $\mathrm{HCO}_{3}^{-}(4.4 \mathrm{meq} / \mathrm{h})$. The mean luminal $\mathrm{HCO}_{3}-$ concentration was similar in all instances. In all these perfusions $\mathrm{pH}$ decreased and $\mathrm{PCO}_{2}$ increased.

When the ECF-like perfusate without $\mathrm{HCO}_{3}^{-}$was used, there was a clear net appearance of $\mathrm{HCO}_{3}^{-}(9.1$ meq $/ \mathrm{h}$; perfusate 4 , Table II).

Chloride diarrhea. In the $\mathrm{CCD}$ patients $\mathrm{Cl}^{-}$movement was greatly reduced (Fig. 2). With the ECF-like perfusate 1 there was practically no net movement of $\mathrm{Cl}^{-}$at all. Clearly, not only influx but also efflux was minimal. Reduction of $\mathrm{Cl}^{-}$concentration in the perfusate caused net secretion of $\mathrm{Cl}^{-}$. In contrast to controls, 


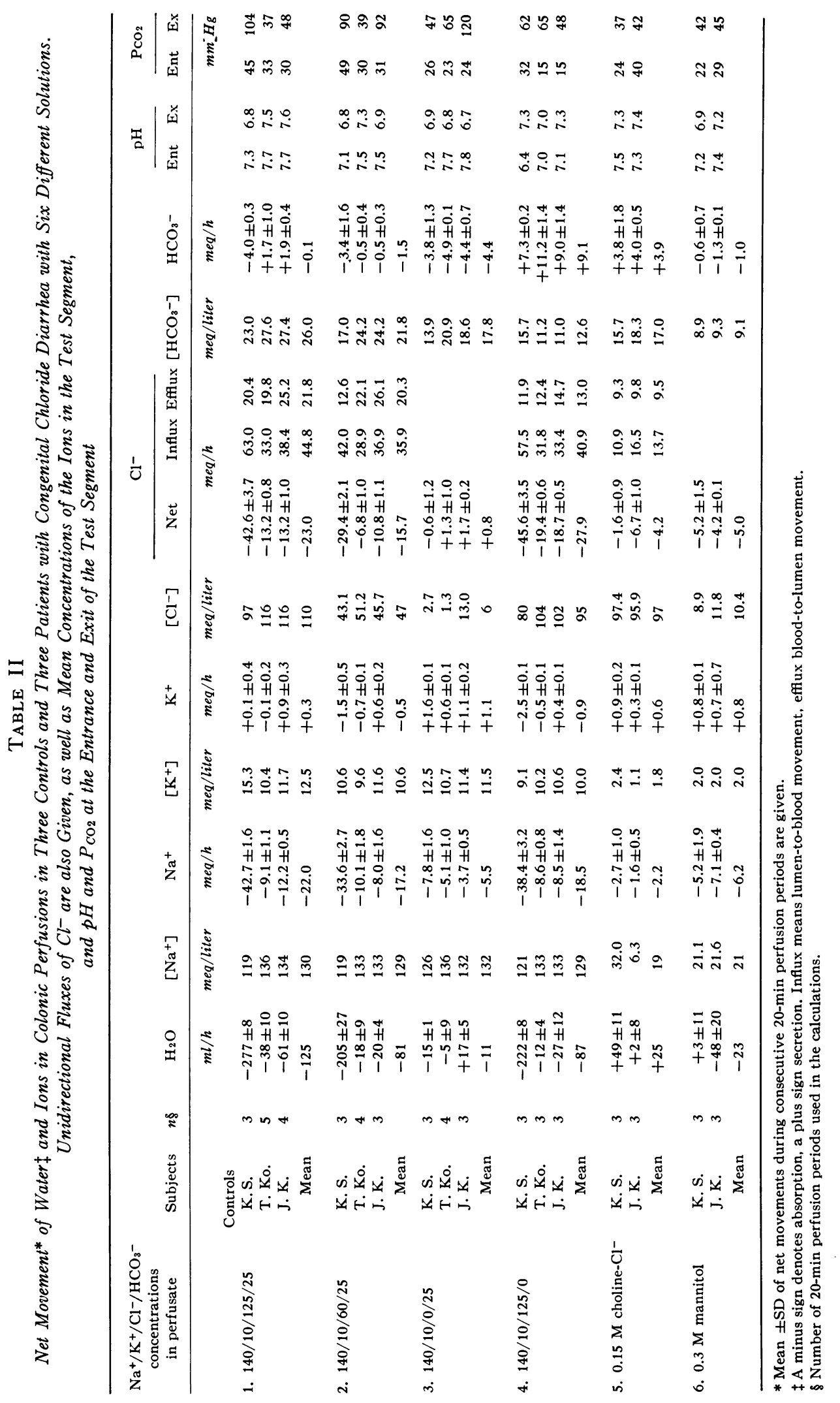




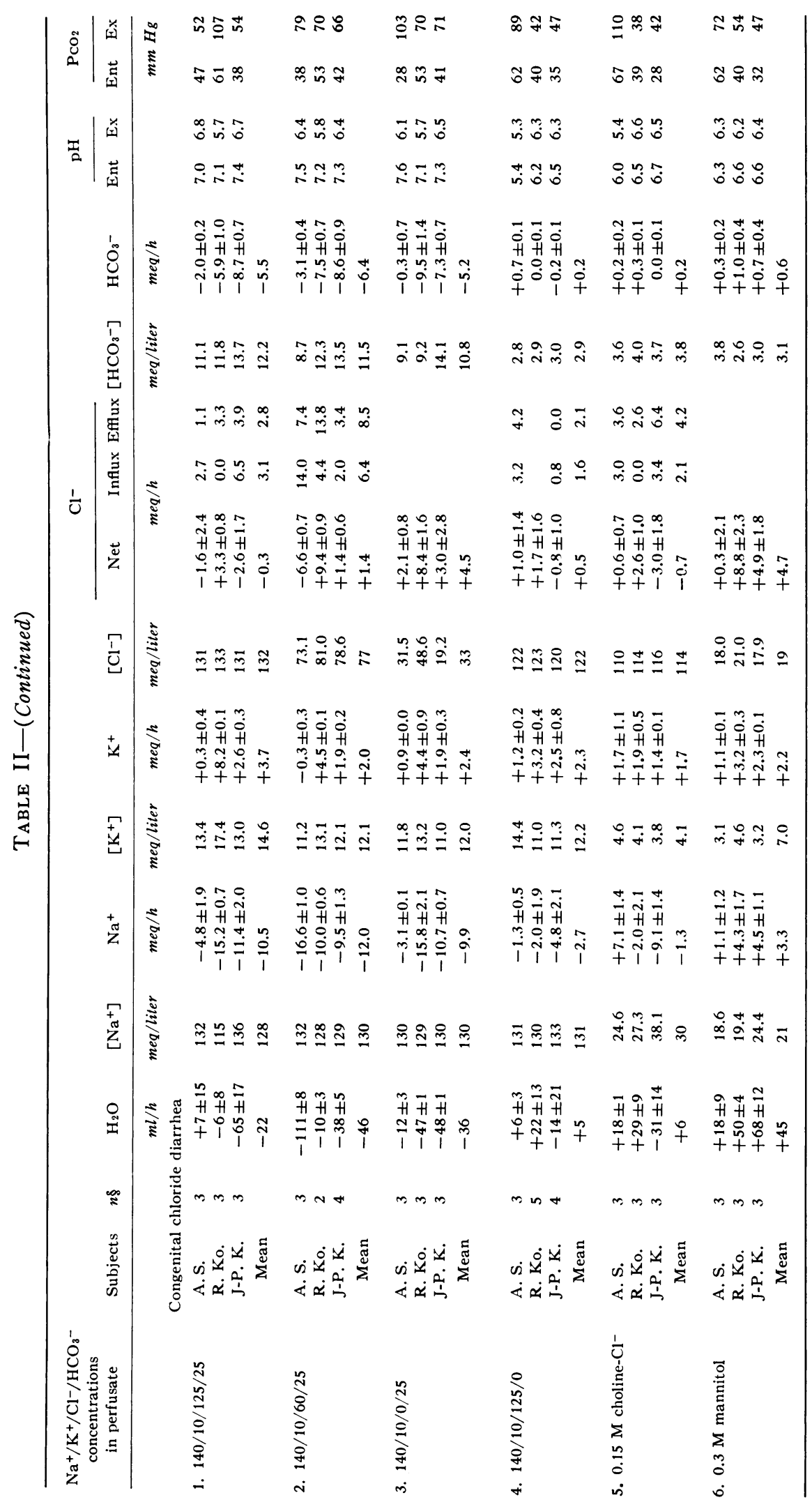

Colonic Electrolyte Transport 
absence of $\mathrm{HCO}_{3}^{-}$did not alter the $\mathrm{Cl}^{-}$movement (Fig. 3). Perfusion with the mannitol solution gave the same slight net secretion of $\mathrm{Cl}^{-}$as was seen with the other $\mathrm{Cl}^{-}$free perfusate 3 (Table II). The mean serum ${ }^{80} \mathrm{Cl}^{-}$activities measured at the end of each perfusion (and corrected for previous, activity) were $266 \mathrm{cpm} / \mathrm{ml}$ (range $75-728 \mathrm{cpm} / \mathrm{ml}, n=8$ ) in the controls, and $43 \mathrm{cpm} / \mathrm{ml}$ (range $13-83 \mathrm{cpm} / \mathrm{ml}, n=7$ ) in the CCD patients. This also demonstrates impaired influx of $\mathrm{Cl}^{-}$.

When ECF-like perfusates of varied $\mathrm{Cl}^{-}$concentration (perfusates 1 to 3 , Table II) were used, there was a net disappearance of $\mathrm{HCO}_{3}^{-}$of similar magnitude (5.2$6.4 \mathrm{meq} / \mathrm{h})$ in all perfusions. This was greater than in the controls, although the mean luminal $\mathrm{HCO}_{3}{ }^{-}$concentration was only half of that in the controls (10.8-12.2 and $17.8-26.0 \mathrm{meq} /$ liter, respectively). $\mathrm{pH}$ fell clearly with a rise of $\mathrm{PCO}_{2}$. The patients had no net appearance of $\mathrm{HCO}_{3}{ }^{-}$in the $\mathrm{HCO}_{3}{ }^{-}$-free $\mathrm{Cl}^{-}$-containing perfusates 4 and 5 , in contrast to the controls (Table II), although they had a much steeper plasma-to-lumen gradient for $\mathrm{HCO}_{3}^{-}$(because of less flow of $\mathrm{HCO}_{3}^{-}$to the segment from the ileum). Changes in $\mathrm{pH}$ and $\mathrm{PCO}_{2}$ were only slight.

\section{$\mathrm{Na}^{+}$transport}

Controls. In perfusions with the ECF-like perfusate there was a mean net $\mathrm{Na}^{+}$absorption of $22.0 \mathrm{meq} / \mathrm{h}$, slightly less than the mean net $\mathrm{Cl}^{-}$absorption. Lowering of $\mathrm{Cl}^{-}$concentration gave a clear decrease in net $\mathrm{Na}^{+}$ absorption (Fig. 2). The slight net absorption of $\mathrm{Na}^{+}$ seen with the $\mathrm{Cl}^{-}$-free perfusate 3 was accompanied by a net disappearance of $\mathrm{HCO}_{s}-$ (Table II). Omission of $\mathrm{HCO}_{3}^{-}$from the ECF-like perfusate did not alter the net $\mathrm{Na}^{+}$movement (Fig. 3). At a mean $\mathrm{Na}^{+}$ concentration of $21 \mathrm{meq} /$ liter or even lower in the test segment there was still a net $\mathrm{Na}^{+}$absorption (solutions 5 and 6 , Table II). Net water movement showed a strong correlation with net $\mathrm{Na}^{+}$movement $\left(\Delta \mathrm{H}_{2} \mathrm{O}\right.$ $(\mathrm{ml} / \mathrm{h})=7.0 \times \Delta \mathrm{Na}^{+}(\mathrm{meq} / \mathrm{h})-32.5 ; \quad r=0.99, \quad P<$ 0.001 ).

Chloride diarrhea. The net $\mathrm{Na}^{+}$absorption was not decreased from the ECF-like perfusate 1 . It was of the same magnitude as in two of the controls (Table II). Thus the $\mathrm{Na}^{+}$-absorbing system was unimpaired.

However, in three respects net $\mathrm{Na}^{+}$absorption in the patients contrasted sharply with that of the controls. (a) Reduction of $\mathrm{Cl}^{-}$concentration in the perfusate did not alter it (Fig. 2). (b) Omission of $\mathrm{HCO}_{s}^{-}$from the perfusate caused a marked decrease in it (Fig. 3). (c) It did not take place from $\mathrm{Na}^{+}$concentrations below 27 meq/liter (solutions 5 and 6 , Table II). In the last two situations the fluid entering the test segment was more acid than in the controls, and the test situation was thus different (mean $\mathrm{pH} 6.4$ in the patients and 7.1 in the controls). Such unusual acidity prevails in the colon in patients with $\mathrm{CCD}$, in whom the ileal effluent has a lower $\mathrm{HCO}_{3}^{-}$concentration and lower $\mathrm{pH}$ than in the controls.

\section{$\mathrm{K}^{+}$transport}

Controls. In most perfusions with solutions containing $\mathrm{K}^{+}$at $10 \mathrm{meq} /$ liter only slight net movement of $\mathrm{K}^{+}$ took place; presumably this concentration was close to the equilibrium concentration. With $\mathrm{K}^{+}$-free perfusates and less than $2 \mathrm{meq} /$ liter of $\mathrm{K}^{+}$in the segment, net secretion was constantly observed.

Chloride diarrhea. In the patients net $\mathrm{K}^{+}$secretion was clearly increased. This was seen in all perfusions, and was most marked in patient $R$. Ko. In the perfusions with $10 \mathrm{meq} / \mathrm{liter} \mathrm{K}^{+}$concentration, the mean increment was $1.3 \mathrm{meq} /$ liter $( \pm 1.7 \mathrm{SD})$ in the controls and $4.8 \mathrm{meq} /$ liter $( \pm 2.7 \mathrm{SD})$ in the patients.

\section{DISCUSSION}

Colonic electrolyte transport in the controls. The control subjects were siblings of our patients. Because $\mathrm{CCD}$ is an autosomal recessive disease, they may have been heterozygotes and may thus have had impaired intestinal electrolyte transport. They were healthy, and showed no signs of impaired intestinal function. Their perfusion results closely resembled those obtained in fasting adults $(19,20)$. Their normality remains unconfirmed, however, because there are no reports of similar studies in normal children or even in nonfasted adults. Because of the lability of the electrolyte balance in $\mathrm{CCD}$, perfusions in fasting could not be considered.

From an ECF-like perfusate we observed net absorption of $\mathrm{Na}^{+}$and $\mathrm{Cl}^{-}$against steep concentration gradients, and slight net appearance of $\mathrm{HCO}_{3}{ }^{-}$. A "coupling" between the movements of $\mathrm{Na}^{+}$and $\mathrm{Cl}^{-}$was evident from two observations. Net absorption of both $\mathrm{Cl}^{-}$ and $\mathrm{Na}^{+}$was diminished when the luminal $\mathrm{Cl}^{-}$concentration was reduced. Omission of $\mathrm{Na}^{+}$from the perfusate (choline- $\mathrm{Cl}^{-}$perfusate) also reduced $\mathrm{Cl}^{-}$influx. As the unidirectional fluxes of $\mathrm{Na}^{+}$were not measured, this coupling could not be further characterized.

With the ECF-like perfusate, the influx of $\mathrm{Cl}^{-}$was twice as great as the efflux. The influx was reduced when the luminal concentration of $\mathrm{Cl}^{-}$was diminished. Omission of $\mathrm{HCO}_{s}^{-}$from the perfusate, on the other hand, clearly reduced the $\mathrm{Cl}^{-}$efflux. This requirement of luminal $\mathrm{HCO}_{3}^{-}$for the efflux of $\mathrm{Cl}^{-}$suggests that this efflux is coupled with the influx of $\mathrm{HCO}_{3}^{-}$. This could be explained if the $\mathrm{Cl}^{-} / \mathrm{HCO}_{3}^{-}$exchange that is suggested in the colon $(19,20)$ takes place in both directions. Evidence for a similar bidirectional exchange has been obtained for the ileum (13). 
Intestinal electrolyte transport in CCD. Studies by Bieberdorf et al. (14) of ileal function in CCD showed that $\mathrm{Na}^{+}$transport is intact but active transfer of $\mathrm{Cl}^{-}$ is lacking. Passive movement of $\mathrm{Cl}^{-}$along the electrochemical gradient was documented. Our finding that the ileal effluent had higher $\mathrm{Cl}^{-}$and lower $\mathrm{HCO}_{3}^{-}$concentrations than in the controls is consistent with these observations.

We have documented a distinct difference in colonic function between our controls and patients. The possible heterozygosity of the controls does not seem to leave the nature of the colonic defect in doubt; if they were heterozygotes the difference between CCD and the truly normal state could only be larger.

The present studies of colonic function in CCD revealed a pattern similar to that found in previous studies of the ileum (14). $\mathrm{Na}^{+}$transport was intact, but net absorption of $\mathrm{Na}^{+}$was dependent on luminal presence of $\mathrm{HCO}_{3}^{-}$, in contrast to the controls. Obviously, electroneutrality requires that absorption of $\mathrm{Na}^{+}$is associated with corresponding absorption of an anion or equivalent secretion of another cation. Thus in the controls net $\mathrm{Na}^{+}$and $\mathrm{Cl}^{-}$movements were closely linked. In $\mathrm{CCD}$, as we have shown, $\mathrm{Cl}^{-}$did not move, and $\mathrm{Na}^{+}$ absorption was balanced by net disappearance of $\mathrm{HCO}_{3}^{-}$ and net secretion of $\mathrm{K}^{+}$. This explains the suppression of $\mathrm{Na}^{+}$absorption on omission of luminal $\mathrm{HCO}_{3}^{-}$. The disappearance of $\mathrm{HCO}_{3}^{-}$may be due to its absorption, or to secretion of $\mathrm{H}^{+}$, or to both of these events simultaneously. The rise of $\mathrm{PCO}_{2}$ that accompanied this disappearance of $\mathrm{HCO}_{3}^{-}$suggests that $\mathrm{H}^{+}$secretion was at least partly responsible. This would imply the existence in the colon of $\mathrm{Na}^{+} / \mathrm{H}^{+}$exchange, a mechanism already postulated for the ileum $(13,14)$. The possibility of a rise in $\mathrm{PCO}_{2}$ through absorption of $\mathrm{HCO}_{3}^{-}$and backdiffusion of $\mathrm{CO}_{2}$ cannot be excluded. Whatever the mechanism(s), it leads to accumulation of $\mathrm{H}^{+}$and exhaustion of $\mathrm{HCO}_{3}{ }^{-}$in the luminal contents and stops the net absorption of $\mathrm{Na}^{+}$.

A clearly increased secretion of $\mathrm{K}^{+}$was noted in all patients. The marked elevation of $\mathrm{K}^{+}$concentration in the anal effluent suggests increased luminal electronegativity, as colonic secretion of $\mathrm{K}^{+}$is at least partly due to passive diffusion along the electrochemical gradient $(20,21)$. Increased intracolonic potential difference has been documented in two CCD patients $(7,12)$. Enhanced aldosterone activity increases potential difference and net secretion of $\mathrm{K}^{+}$into the human colon (2225 ), and such enhanced activity has been recorded in $\operatorname{CCD}(5,7,10,11,26)$. Urinary aldosterone excretion was $43.4 \mu \mathrm{g} / \mathrm{m}^{2} \cdot$ day in R. Ko. and $23.2 \mu \mathrm{g} / \mathrm{m}^{2} \cdot$ day in J-P. K. (normal $<12 \mu \mathrm{g} / \mathrm{m}^{2} \cdot$ day). This may mediate the increased $\mathrm{K}^{+}$secretion observed. It is an interesting possibility that cation exchange is increased in $\mathrm{CCD}$, which secretes $\mathrm{K}^{+}$along with $\mathrm{H}^{+}$in exchange for $\mathrm{Na}^{+}$. Evidence for the presence of such a mechanism has been observed for frog colon (27).

The primary defect in the colon, as in the ileum, is one of $\mathrm{Cl}^{-}$transport. With the ECF-like perfusate no transfer of $\mathrm{Cl}^{-}$was seen, but both influx and efflux were practically absent. Only with steep gradients was a slight net secretion of $\mathrm{Cl}^{-}$observed. Alteration of luminal $\mathrm{Cl}^{-}$concentration did not affect the net change of luminal $\mathrm{HCO}_{3}^{-}$content. Net appearance of $\mathrm{HCO}_{3}^{-}$was not seen with the $\mathrm{HCO}_{3}^{-}$-free $\mathrm{Cl}^{-}$containing perfusates, in contrast to controls. If $\mathrm{HCO}_{3}{ }^{-}$was secreted, but disappeared because of the greater acidity of the colonic contents in the patients, the rise of $\mathrm{PCO}_{2}$ should have been larger than in the controls. This never occurred. Thus no evidence for secretion of $\mathrm{HCO}_{3}^{-}$was obtained in the patients.

Nature of the basic defect. As $\mathrm{Cl}^{-}$transport is impaired in both ileum and colon, it is logical to assume that the same defect is present in both. A hypothesis to account for the defect has to explain the difference in $\mathrm{Cl}^{-}$movement between the two parts of the intestine; while the unidirectional fluxes in the ileum were almost normal (14), they were practically absent from the colon. A defect in permeability to $\mathrm{Cl}^{-}$would explain the colonic findings, but is incompatible with the ileal ones.

Could absence of active $\mathrm{Cl}^{-} / \mathrm{HCO}_{3}^{-}$transfer, such as was proposed by Bieberdorf et al. for the ileum (14), explain our findings for the colon? Evidence has been obtained that $\mathrm{Cl}^{-} / \mathrm{HCO}_{3}^{-}$exchange occurs in the normal human colon $(19,20)$; this exchange has features of active transport $(20,21,28,29)$. The permeability of the intestine is known to decrease in the distal direction (18, 30-32). Conceivably, although an essential part of the $\mathrm{Cl}^{-}$fluxes may take place through independent passive diffusion in the ileum, such movement may virtually fail to occur in the poorly permeable colon. The carrier-mediated $\mathrm{Cl}^{-} / \mathrm{HCO}_{3}^{-}$exchange may thus be necessary for any $\mathrm{Cl}^{-}$flux in the colon. A defect in this mechanism would then explain the observed absence of active $\mathrm{Cl}^{-}$transport in the ileum and all $\mathrm{Cl}^{-}$movement in the colon. The apparent absence of $\mathrm{HCO}_{3}{ }^{-}$secretion in the colon is consistent with this theory.

Bieberdorf et al. (14) observed a slight increase in downhill $\mathrm{Cl}^{-}$secretion on elevation of luminal $\mathrm{HCO}_{3}^{-}$ concentration to $80 \mathrm{meq} / \mathrm{liter}$ in the ileum of their CCD patient. This suggest that in that patient the $\mathrm{Cl}^{-} / \mathrm{HCO}_{3}^{-}$ exchange mechanism was not totally lacking, but was capable only of passive function at a very high luminal $\mathrm{HCO}_{3}{ }^{-}$concentration.

In conclusion, present knowledge of intestinal transport in CCD is compatible with the notion that the basic defect is impairment or absence of a $\mathrm{Cl}^{-} / \mathrm{HCO}_{3}^{-}$ exchange mechanism, which operates in both directions 
in the normal ileum and colon. Such a defect explains the clinical findings in CCD: large watery stools with high $\mathrm{Cl}^{-}$concentration and very low $\mathrm{HCO}_{3}^{-}$concentration and $\mathrm{pH}$. The passive permeability of the proximal intestine to $\mathrm{Cl}^{-}$explains the success of oral replacement therapy.

\section{ACKNOWLEDGMENTS}

We wish to thank Mrs. Maija-Liisa Taalikka for skillful technical assistance.

This work has been supported by grants from the National Research Council for Medical Sciences, Finland, and the Foundation for Pediatric Research, Helsinki, Finland.

\section{REFERENCES}

1. Gamble, J. L., K. R. Fahey, J. Appleton, and E. MacLachlan. 1945. Congenital alkalosis with diarrhea. $J$. Pediatr. 26: 509-518.

2. Darrow, D. C. 1945. Congenital alkalosis with diarrhea. J. Pediatr. 26: 519-532.

3. Evanson, J. M., and S. W. Stanbury. 1965. Congenital chloridorrhoea or so-called congenital alkalosis with diarrhoea. Gut. 6: 29-38.

4. Norio, R., J. Perheentupa, K. Launiala, and N. Hallman. 1971. Congenital chloride diarrhea, an autosomal recessive disease. Clin. Genet. 2: 182-192.

5. Davidson, A. G. F., J. Insley, F. P. A. Capps, and C. M. Andersson. 1972. Familial chloride diarrhoea. Aust. Paediatr. J. 8: 187-190.

6. Michalsen, H. 1972. Congenital chloride diarrhoea. Acto Pacdiatr. Scand. 61: 615-618.

7. Pearson, A. J. G., G. E. Sladen, C. J. Edmonds, A. S. Tavill, M. R. Wills, and N. McIntyre. 1973. The pathophysiology of congenital chloridorrhoea. Q.J. Med. 42: $453-466$.

8. Lee, T. R., and J. T. Harries. 1973. Congenital chloridorrhoea. Proc. R. Soc. Med. 66: 348-349

9. Bremer, D., and H.-M. Heinisch. 1973. Bilanzuntersuchungen bei einem Säugling mit congenitaler Chloridiarrhoe. Monatsschr. Kinderheilkd. 121: 403-405.

10. Lauras, B., B. Francois, H. Duc, J. Genoud, M. David, and M. Jeune. 1973. Contributions a l'etude de la diarrhee chloree congenitale. Arch. Fr. Pédiatr. 30: 491503.

11. Launiala, K., J. Perheentupa, A. Pasternack, and N. Hallman. 1967. Familial chloride diarrhea-chloride malabsorption. Mod. Probl. Pediatr. 11: 137-149.

12. Turnberg, L. A. 1971. Abnormalities in intestinal electrolyte transport in congenital chloridorrhoea. Gut. 12: 544-551.

13. Turnberg, L. A., F. A. Bieberdorf, S. G. Morawski, and J. S. Fordtran. 1970. Interrelationships of chloride, bicarbonate, sodium, and hydrogen transport in the human ileum. J. Clin. Invest. 49: 557-567.

14. Bieberdorf, F. A., P. Gorden, and J. S. Fordtran. 1972. Pathogenesis of congenital alkalosis with diarrhea. $J$. Clin. Invest. 51 : 1958-1968.
15. Launiala, K. 1969. The effect of unabsorbed sucrose or mannitol induced accelerated transit on absorption in the human small intestine. Scand. J. Gastroenterol. 4: 2531 .

16. Levitan, R., J. S. Fordtran, B. A. Burrows, and F. J. Ingelfinger. 1962. Water and salt absorption in the human colon. J. Clin. Invest. 41: 1754-1759.

17. Curran, P. F., and A. K. Solomon. 1958. Ion and water fluxes in the ileum of rats. J. Gen. Physiol. 41: 143-168.

18. Billich, C. O., and R. Levitan. 1969. Effects of sodium concentration and osmolality on water and electrolyte absorption from the intact human colon. J. Clin. Invest. 48: 1336-1347.

19. Devroede, G. J., and S. F. Phillips. 1969. Conservation of sodium, chloride, and water by the human colon. Gastroenterology. 56: 101-109.

20. Giller, J., and S. F. Phillips. 1972. Electrolyte absorption and secretion in the human colon. Am. J. Dig. Dis. 17 : 1003-1011.

21. Cooperstein, J. L., and S. K. Brockman. 1959. The electrical potential difference generated by the large intestine; its relation to electrolyte and water transfer. $J$. Clin. Invest. 38: 435-442.

22. Shields, R., A. T. Mulholland, and R. G. Elmslie. 1966. Action of aldosterone upon the intestinal transport of potassium, sodium, and water. Gut. 7: 686-696.

23. Edmonds, C. J., and J. C. Marriott. 1967. The effect of aldosterone and adrenalectomy on the electrical potential difference of rat colon and on the transport of sodium, potassium, chloride, and bicarbonate. J. Endocrinol. 39 : 517-531.

24. Shields, R., J. B. Miles, and C. Gilbertson. 1968. Absorption and secretion of water and electrolytes by the intact colon in a patient with primary aldosteronism. Br. Med. J. 1 : 93-96.

25. Richards, P. 1969. Clinical investigation of the effects of adrenal corticosteroid excess on the colon. Lancet. 1: $437-442$.

26. Jeune, M., M. Hermier, E. Hartemann, B. Loras, F. Haour, J. B. Cotton, and C. Collombel. 1967. Diarrhée chlorée congenitale avec alcalose metabolique. Pédiatrie. 22: 663-668

27. Perheentupa, J., H. C. Harrison, and H. E. Harrison. 1972. Electrolyte transport by bullfrog colon in vitro. Biochim. Biophys. Acta. 255: 858-872.

28. Binder, H. J. 1973. A model of large intestinal electrolyte transport. Clin. Res. 21: 508. (Abstr.)

29. Schultz, S. G., and R. A. Frizzell. 1972. An overview of intestinal absorptive and secretory process. Gastroenterology. 63 : 161-170.

30. Goldschmidt, S., and A. B. Dayton, 1919. Studies in the mechanism of absorption from the intestine. I. The colon. A contribution to the one-sided permeability of the intestinal wall to chloride. Am. J. Physiol. 48: 419-432.

31. Curran, P. F., and G. F. Schwartz. 1960. Na, Cl and water transport by rat colon. J. Gen. Physiol. 43: 555571.

32. Fordtran, J. S., F. C. Rector, Jr., M. F. Ewton, N. Soter, and J. Kinney. 1965. Permeability characteristics of the human small intestine. J. Clin. Invest. 44 : 19351944. 